\title{
Sida acuta Burm.f. leaves ethanol extract ameliorates haematological and biochemical alterations induced by Plasmodium berghei ANKA-65 in mice
}

Osmond Chukwuma Enechi ${ }^{1}$ (D), Christian Chijioke Amah ${ }^{1}$ (D), Innocent Uzochukwu Okagu ${ }^{2^{*}}$ (D), Pamela Chidinma Ononiwu ${ }^{1}$, Alice Chinwendu Nweke ${ }^{1}$ (D) Theophilus Chukwudi Ugwuanyi ${ }^{1}$ (D), Emmanuel Arinzechukwu Ajibo ${ }^{1}$ (D) Anthonia Chiamaka Nweze ${ }^{1}$ (D) and Blessing Chiamaka Chukwurah ${ }^{1}$ (i)

\begin{abstract}
Background: Malaria has continued to be a threat to man and his wellbeing, especially Africans and Asians. New antimalarial drugs are urgently needed to mitigate malaria treatment failure due to resistant Plasmodium species. Medicinal plants used by indigenous Nigerians for treating fever and malaria such as Sida acuta Burm.f. (Malvaceae) could be a promising source of lead compounds for developing new generations of antimalarial drugs. The effects of ethanol extract of $S$. acuta leaves (EESAL) on malaria parasitemia, haematological and biochemical status of $P$. berghei-infected mice were investigated, using the 4-day curative test.

Methodology: EESAL was prepared by maceration method. The phyto-constituents and acute toxicity profile of the extract were evaluated using standard protocols. In addition, malaria parasitemia and chemo-suppression, and indicators of haematological and biochemical status of $P$. berghei-infected mice treated with EESAL were assessed.

Results: At 200, 400 and 600 mg/kg/d b.w., p.o doses for 4 consecutive days, EESAL significantly $(p<0.05)$ decreased parasitaemia and suppressed malaria parasite by $89.64 \%, 95.95 \%$ and $97.38 \%$, respectively comparable to negative control. The reduction in percentage malaria parasitemia by EESAL is comparable to Artemether ( $140 \mathrm{mg} /$ $\mathrm{kg} / \mathrm{d}$ b.w., p.o) used as standard antimalarial drug in this study. The packed cell volume (PCV), haemoglobin ( $\mathrm{Hb})$ concentration, and red blood cell (RBC) and white blood cell (WBC) counts of negative control are significantly $(p<$ $0.05)$ higher than normal control. However, parasitized-EESAL-treated mice have significantly $(p<0.05)$ higher PCV value, $\mathrm{Hb}$ concentration and RBC and WBC counts than negative control. Similarly, treatment of parasitized mice with EESAL restored some indicators of the antioxidant, lipid peroxidation, lipid profile and liver status altered by malaria. In addition, EESAL was tolerable up to $5000 \mathrm{mg} / \mathrm{kg}$ b.w., p.o.
\end{abstract}

Conclusion: These results indicate that the EESAL possesses antimalarial activity and normalizes alterations in haematological and biochemical status of malaria-infected mice.

Keywords: Sida acuta Burm.f., Plasmodium berghei, Malaria, Haematological indices, Biochemical parameters

\footnotetext{
* Correspondence: innocent.okagu@unn.edu.ng

${ }^{2}$ Department of Biochemistry, Medical Parasitology, Toxicology and Drug

development Unit, University of Nigeria, Nsukka, Enugu State, Nigeria

Full list of author information is available at the end of the article
}

(c) The Author(s). 2021 Open Access This article is licensed under a Creative Commons Attribution 4.0 International License, which permits use, sharing, adaptation, distribution and reproduction in any medium or format, as long as you give appropriate credit to the original author(s) and the source, provide a link to the Creative Commons licence, and indicate if changes were made. The images or other third party material in this article are included in the article's Creative Commons licence, unless indicated otherwise in a credit line to the material. If material is not included in the article's Creative Commons licence and your intended use is not permitted by statutory regulation or exceeds the permitted use, you will need to obtain permission directly from the copyright holder. To view a copy of this licence, visit http://creativecommons.org/licenses/by/4.0/. 


\section{Introduction}

Malaria is a parasitic disease caused by Plasmodium species that causes high annual numbers of hospital visits and deaths globally with higher impact in Sub-Saharan Africa and South-East Asia [1]. Out of the 228 million cases of malaria globally in 2018, 213 million are from the WHO African Region, and Nigeria contributed 25\% of this number [2]. This high burden of the disease demands concerted interventions to reduce the impact on man to barest minimum. Current efforts to eliminate malaria have been hampered by antimalarial resistance $[3,4]$, and worrisome adverse effects of current antimalarials [5]. This situation necessitates the hunt for new, cheap and effective antimalarial drugs especially from natural products such as plants to avoid getting to an era when malaria will become incurable.

Alterations in the haematological profile such as lymphopenia, anaemia, thrombocytopenia, eosinopenia, neutropenia, monocytosis and leucocytosis are prominent indicators of severity of malaria infection [6]. Recently, oxidative stress has been identified as one of the complications in malaria [7]. Furthermore, the existence of dyslipidemia in malaria is well recognized. Mohanty et al. [8] reported significant elevation in total cholesterol (CHOL) and low-density lipoproteins (LDL) while high density lipoproteins (HDL) and triacylglycerols (TAGs) decreased significantly. It was also reported that the extent of dyslipidemia is dependent on the severity of the disease $[9,10]$. Similar studies in both vivax and falciparum malaria patients reported that concentrations of HDL, LDL, and CHOL decreased significantly but TAGs increased in malaria-infected patients than in healthy control [11-15]. These reports generally support the opinion that malaria induces dyslipidaemia and hence, a good antimalarial agent should, in addition to clearing malaria parasite, restore homeostasis in lipid status.

Medicinal plants employed in treating fever and malaria by traditional healers is suggested to be potential sources of a new generation of antimalarials. Sida acuta Burm.f. (Malvaceae), also known as Wirewood and Udo in English and Igbo languages, respectively, is among the common plants traditionally used for treating malaria in Nigeria and other parts of Africa [16-19]. Extracts from the plant have been shown to have larvicidal effects on Anopheles stephensi [20], anti-plasmodial [21], analgesic [22], antibacterial [23], antioxidant [24], anxiolytic and neuromodulatory [25] activities. The present research was designed to reveal some of the phytochemical constituents and investigate the acute toxicity profile and in vivo malaria-curative activity of the ethanol extract of S. acuta leaves (EESAL). The effect of ESAL on some altered haematological and biochemical (lipid profile, antioxidant and lipid peroxidation and liver status) parameters of $P$. berghei-infected mice was also investigated.

\section{Materials and methods}

\section{Chemicals and instruments}

Instruments used were weighing balance (Vickas Ltd., England), centrifuge (Vickas Ltd., England), microscope (SMDM-1030, Ted Pella Inc. USA) and spectrophotometer (E312 Model) (Jenway, UK) while reagents for the biochemical experiments were products of Randox (USA). Solvents used (ethanol, ethyl acetate, chloroform and n-hexane) were products of JHD (India) while other chemicals were products of Sigma-Aldrich (USA). All chemicals used were of analytical grade, received in good condition and were freshly prepared before use.

\section{Study animals}

Fifty-four adult Swiss albino mice of average body weight of $30 \pm 5 \mathrm{~g}$ were used for this study; 18 and 36 mice for acute toxicity and antimalarial studies, respectively. The mice were maintained on commercial feed (Chukun Feeds Nig. Ltd.) and water ad libitum. The study was approved by the Faculty of Biological Sciences Committee on Research and Bioethics (UNN/FBS/EC/ 1022). The study animals were ethically handled throughout the experimental period in accordance with the institutional, national and international ethical recommendations for care and use of laboratory animals.

\section{Standard drug}

Artemether (a combination of artemether and lumenfantrin, 80:480 w/w, Ajanta Pharma Ltd., India) was the standard antimalarial of choice in this study.

\section{Extraction of plant materials}

In June of 2019, fresh leaves of S. acuta Burm.f. (Malvaceae) were collected from its natural habitat in OpandaNimbo, Enugu State, Nigeria and were authenticated by Mr. Alfred Ozioko, a taxonomist of the Bioresources Development and Conservation Programme (BDCP) Research Centre, Nsukka, Enugu State (voucher number Intercedd/160). This was compared with features available in the plant database (http://www.theplantlist.org/) for confirmation. Two weeks air-dried leaves of S. acuta plant were powdered and the powder was extracted thrice with ethanol by cold maceration method. Filtrates from the extraction chambers were dried (rotary evaporator at $45^{\circ} \mathrm{C}$ ), obtaining crude ethanol leaf extract of $S$. acuta (EESAL) (13.32\%). Ethanol was used as a solvent in this study based on the traditional practice where the leaves are soaked in ethanol for 2-3 days and the decoction orally taken for 4-7 days to treat malaria [16, 26, 27]. In addition, results of pilot study conducted using different solvent extracts showed that ethanol extract has significantly higher activity compared to n-hexane, ethyl acetate, water and chloroform extracts (data not shown). 


\section{Phytochemical analysis of EESAL}

The quantitative secondary metabolites in EESAL were determined using standard procedures described by Trease and Evans [28] and Harborne [29] as per [30]. The procedures are briefly presented below.

\section{Detection and quantification of tannins in EESAL}

Using ferric chloride assay, the presence of tannins in the extract was determined using the method of the methods of Trease and Evans (1989). Extract (0.1 g) was stirred with $10 \mathrm{ml}$ of distilled water and then filtered. The appearance of blue-black precipitate when three drops of $1 \%$ ferric chloride solution were added to $2 \mathrm{ml}$ of the filtrate indicated the presence of tannins. Thereafter, the amount of total tannins in the sample was quantified using the method of Harborne (1973). To 5 $\mathrm{ml}$ of the filtrate above in a test tube, $0.1 \mathrm{~N}$ ferric chloride in $0.1 \mathrm{~N} \mathrm{HCl}$ and $0.008 \mathrm{M}$ potassium ferricyanide were added and mixed. The absorbance of the mixture was read at $720 \mathrm{~nm}$. The tannin content of the extract was extrapolated from a tannic acid standard curve.

\section{Detection and quantification of alkaloids in EESAL}

The alkaloids in EESAL were detected by Dragendorff's reagent test following the methods of Trease and Evans (1989). Briefly, $0.1 \mathrm{~g}$ of EESAL was boiled with $5 \mathrm{ml}$ of $1 \%$ aqueous $\mathrm{HCl}$ on a water bath for $10 \mathrm{~min}$ and filtered. The appearance of orange-red precipitate on addition of 2 drops of Dragendorff's reagent to $1 \mathrm{ml}$ of the filtrate indicated the presence of alkaloids. Following the method of Harborne (1973), the quantity of total alkaloids in EESAL was determined. EESAL $(0.1 \mathrm{~g})$ was macerated in $20 \mathrm{ml}$ of $20 \% \mathrm{H}_{2} \mathrm{SO}_{4}$ in ethanol (1:1) for $30 \mathrm{~min}$ and was filtered. To $1 \mathrm{ml}$ of the filtrate, $5 \mathrm{ml}$ of $60 \%$ $\mathrm{H}_{2} \mathrm{SO}_{4}$ was added and after $5 \mathrm{~min}, 5 \mathrm{ml}$ of $0.5 \%$ formaldehyde in $60 \% \mathrm{H}_{2} \mathrm{SO}_{4}$ was also added, mixed and allowed to stand for $3 \mathrm{~h}$. The absorbance of the mixture was read at a wavelength of $550 \mathrm{~nm}$. The alkaloid content was extrapolated from an atropine standard curve.

\section{Detection and quantification of glycosides in EESAL}

The presence of glycosides in EESAL was detected using Fehling's test as described by Trease and Evans (1989). Briefly, $0.1 \mathrm{~g}$ of EESAL was mixed with $30 \mathrm{ml}$ of distilled water and heated on a water bath for $5 \mathrm{~min}$, cooled and was filtered. To $5 \mathrm{ml}$ of the filtrate, a mixture of $0.2 \mathrm{ml}$ of each of Fehling's solutions A and B was added drop by drop till $\mathrm{pH}$ changes to alkaline $(\mathrm{pH} \sim 8)$. The appearance of a brick-red precipitate on heating in water bath for $2 \mathrm{~min}$ indicated the presence of glycosides. To $0.1 \mathrm{~g}$ EESAL, $20 \mathrm{ml}$ of distilled water and $2.5 \mathrm{ml}$ of $15 \%$ lead acetate were added, mixed and allowed to stand for 30 min and was filtered. To $2 \mathrm{ml}$ of the filtrate, $2.5 \mathrm{ml}$ of chloroform was added and shaken vigorously and allowed to stand for $5 \mathrm{~min}$. The lower layer was collected into a beaker and was evaporated to dryness in a water bath. Thereafter, $3 \mathrm{ml}$ of glacial acetic acid, $0.1 \mathrm{ml}$ of $5 \%$ ferric chloride and $0.25 \mathrm{ml}$ of concentrated $\mathrm{H}_{2} \mathrm{SO}_{4}$ were added to the beaker, mixed very well and allowed to stand in a dark chamber for $2 \mathrm{~h}$. Thereafter, absorbance of the resultant mixture was measured at $530 \mathrm{~nm}$ against the reagent blank (not containing EESAL).

$$
\begin{aligned}
& \text { Glycoside content }(\mathrm{mg} / 100 \mathrm{~g}) \\
& \qquad=\frac{\text { Absorbance of the sample }}{\text { Absorbance of the sample-Absorbance of the blank }} \times 100
\end{aligned}
$$

\section{Detection and quantification of terpenoids in EESAL}

The existence of terpenoids in EESAL was detected by acetic anhydride test following the procedure of Trease and Evans (1989). EESAL (0.1 g) was dissolved in $5 \mathrm{ml}$ of ethanol and $1 \mathrm{ml}$ of acetic anhydride and drops of concentrated $\mathrm{H}_{2} \mathrm{SO}_{4}$ were added. A change in colour from pink to violet indicated the presence of terpenoids. To determine the quantity of terpenoids in the sample, a quantity $(0.1 \mathrm{~g})$ of EESAL was macerated in $20 \mathrm{ml}$ of ethanol for $10 \mathrm{~min}$ and was filtered. To $1 \mathrm{ml}$ of the filtrate, $1 \mathrm{ml}$ of $5 \%$ phosphomolybdic acid solution was added and shaken, followed by gradual addition of $1 \mathrm{ml}$ of concentrated $\mathrm{H}_{2} \mathrm{SO}_{4}$. The mixture was left to stand for $30 \mathrm{~min}$ and thereafter, $2 \mathrm{ml}$ of ethanol was added and absorbance was measured at $700 \mathrm{~nm}$ against the reagent blank. The terpenoid content was estimated as follows;

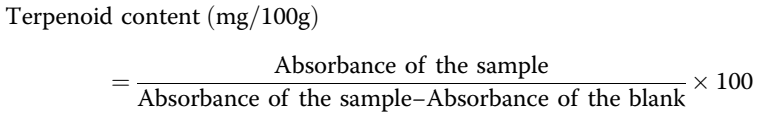

\section{Detection and quantification of flavonoids in EESAL}

Using the lead acetate test, the presence of flavonoids in EESAL was detected as per Trease and Evans (1989). To $5 \mathrm{ml}$ of the filtrate from the tannins test, $3 \mathrm{ml}$ of lead acetate solution was added. The formation of yellowish precipitate indicated the presence of flavonoids. To quantify the amount of total flavonoids in EESAL, $0.1 \mathrm{~g}$ of the sample was macerated in $20 \mathrm{ml}$ of ethyl acetate, and the suspension was filtered. To $5 \mathrm{ml}$ of the filtrate, $5 \mathrm{ml}$ of dilute ammonia was added, mixed and allowed to separate into two layers. The upper layer of the mixture, containing the flavonoids was collected and the absorbance was read at $510 \mathrm{~nm}$ using ethyl acetate as the blank. The concentration of flavonoids in the extract was extrapolated from a catechin standard curve.

\section{Detection and quantification of steroids in EESAL}

To $0.1 \mathrm{~g}$ of EESAL, $2 \mathrm{ml}$ of acetic acid was added and mixed thoroughly. The solution was cooled in ice followed by the addition of concentrated tetraoxosulphate (VI) acid 
$\left(\mathrm{H}_{2} \mathrm{SO}_{4}\right)$. The formation of a violet ring which turns bluish on addition of acid indicated the presence of steroids. To quantify the content of steroids in EESAL, $0.1 \mathrm{~g}$ of the sample was macerated in $20 \mathrm{ml}$ of ethanol and filtered. To $2 \mathrm{ml}$ of the filtrate, $2 \mathrm{ml}$ of chromogen solution (4 $\mathrm{ml}$ ferric chloride stock made up to $24 \mathrm{ml}$ with concentrated $\mathrm{H}_{2} \mathrm{SO}_{4}$ ) and $1 \mathrm{ml}$ of $0.5 \%$ potassium hexacyanoferrate (III) solution were added, mixed and the mixture was left to stand for $30 \mathrm{~min}$ in a water bath set at $70^{\circ} \mathrm{C}$. Thereafter, the mixture was cooled and made up to $10 \mathrm{ml}$ with distilled and the absorbance was measured at $780 \mathrm{~nm}$ against the reagent blank (prepared by adding all the reagents except in the sample test tube except the extract).

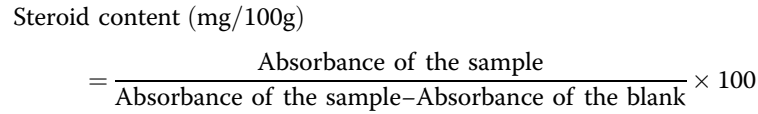

\section{Detection and quantification of phenols in EESAL}

The presence of phenols in EESAL was detected by ferric chloride test following the method of Trease and Evans (1989). To $2 \mathrm{ml}$ of the filtrate from tannin test, few drops of $10 \%$ ferric chloride solution were then added. The appearance of a greenish-blue or violet colour indicated the presence of a phenolic hydroxyl group. To determine the quantity of phenolic compounds in EESAL, the Folin-ciocalteu's reagent test method of Harborne (1973) was adopted. To quantify the amount of phenols in EESAL, $0.1 \mathrm{~g}$ was macerated in $20 \mathrm{ml}$ of $80 \%$ ethanol and filtered. To $5 \mathrm{ml}$ of the filtrate, $0.5 \mathrm{ml}$ of Folinciocalteu's reagent was added and allowed to stand for 3 min. This was followed by the addition of $2 \mathrm{ml}$ of $20 \%$ sodium carbonate (IV) and the mixture was left to stand for $10 \mathrm{~min}$. The absorbance of the resultant mixture was measured at $765 \mathrm{~nm}$ against the reagent blank.

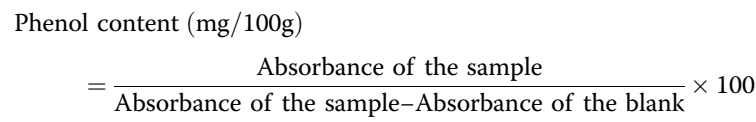

\section{Acute toxicity test}

The acute toxicity profile of the plant extract was determined in two phases using a method described by Lorke [31]. A total of 18 mice were used for this test. In phase I, nine mice were divided into three groups of three mice each (groups 1-3 received 10, 100 and $1000 \mathrm{mg} / \mathrm{kg}$ b.w of EESAL, respectively). The mice were observed for $24 \mathrm{~h}$ for signs of toxicity and lethality. Thereafter, the remaining nine mice were randomized into three groups of three mice each (groups 4-6 received 1600, 2900 and $5000 \mathrm{mg} /$ $\mathrm{kg}$ b.w of EESAL, respectively). These mice were again observed for $24 \mathrm{~h}$ for signs of toxicity and lethality. Body weight of the mice $24 \mathrm{~h}$ post-EESAL administration were measured and compared with the initial body weight.

\section{Parasite inoculation}

Plasmodium berghei-infected blood from a donor mouse was used for inoculum preparation. The blood was diluted serially in Alsever's solution to make a suspension containing about $1 \times 10^{7}$ infected RBCs in every $0.2 \mathrm{~mL}$ suspension. The mice in test groups (groups 2-6) were intraperitoneally inoculated with $0.2 \mathrm{~mL}$ of this suspension to initiate infection. Malaria parasite infection was confirmed $72 \mathrm{~h}$ post-infection.

\section{Experimental design for malaria curative study}

Thirty-six adult Swiss mice used for this study were divided into six groups of six mice each as follows:

Group $1=$ Normal control (administered with the vehicle, normal saline)

Group 2 = Negative control (inoculated with malaria parasite and untreated)

Group 3 = Standard drug control (P. berghei-parasitized $+140 \mathrm{mg} / \mathrm{kg}$ b.w. of Artemether).

Group $4=$ P. berghei-parasitized $+200 \mathrm{mg} / \mathrm{kg}$ b.w. of EESAL.

Group $5=P$. berghei-parasitized $+400 \mathrm{mg} / \mathrm{kg}$ b.w. of EESAL.

Group $6=$ P. berghei parasitized $+600 \mathrm{mg} / \mathrm{kg}$ b.w. of EESAL.

Treatment lasted for 4 days (from day 0-day 3 ) and on day 4, overnight fast blood sample was collected from each of the mouse for parasitaemia count, haematological and biochemical (lipid peroxidation, antioxidant and liver status, and lipid profile) analyses. The three doses were selected based on activity-guided dose selection from pilot study.

Determination of malaria parasitemia in parasitized mice Malaria parasitaemia was determined by methods described earlier [32,33] and the percentage malarial parasitemia and chemosuppression were calculated using the relations below:

$$
\begin{aligned}
& \text { \%Malaria Parasitemia (MP) } \\
& =\frac{\text { Number of parasitized RBCs }}{\text { Total number of RBCs counted }} \times 100 \\
& \text { \%Malaria Chemosuppression } \\
& =\frac{\text { Day0 MP-Day3 MP }}{\text { Day0 MP }} \times 100
\end{aligned}
$$

\section{Determination of haematological and some biochemical status of experimental mice}

Haematological indices were determined by previous methods [34, 35]. Aspartate and alanine aminotransferases (AST and ALT) and alkaline phosphatase (ALP) 
activities were assayed using previously described methods [36, 37] as contained in the Randox commercial kits. Serum total bilirubin [38], CHOL [39], and HDL and TAG concentrations were determined using colorimetric methods [40] as contained in Randox commercial kits. Serum LDL level was determined as the difference between $\mathrm{CHOL}$ and the cholesterol content of the supernatant after precipitation of the LDL fraction by polyvinyl sulphate (PVS) in the presence of polyethylene glycol monomethyl ether. The extent of lipid peroxidation (level of malondialdehyde (MDA)) was measured as per known protocol [41]. Superoxide dismutase (SOD) and catalase (CAT) activities were assayed using methods earlier described $[42,43]$, respectively while the reduced glutathione (GSH) concentration was determined according to method described by Kings and Wootton [44].

\section{Statistical analysis}

Primary data from the laboratory were analyzed using one way analysis of variance in Statistical Product and Service Solution version 20.0 (IBM Inc., USA) and Dunnett's post hoc test was used to compare means across the groups. The results were presented as mean \pm standard deviation (SD) in tables and mean values with $p<$ 0.05 were considered significant.

\section{Results}

Phytochemical composition of EESAL

As shown in Table 1, the phytochemical compositions of EESAL include tannins $(573.28 \pm 30.74 \mathrm{mg} / 100 \mathrm{~g})$, terpenoids $(161.75 \pm 3.12 \mathrm{mg} / 100 \mathrm{~g})$, steroids $(0.41 \pm 0.08 \mathrm{mg} /$ $100 \mathrm{~g})$, phenols $(3115.16 \pm 143.23 \mathrm{mg} / 100 \mathrm{~g})$, alkaloids $(4.62 \pm 1.04 \mathrm{mg} / 100 \mathrm{~g})$, flavonoids (2051.44 $\pm 84.32 \mathrm{mg} /$ $100 \mathrm{~g})$ and glycosides $(108.54 \pm 12.71 \mathrm{mg} / 100 \mathrm{~g})$.

\section{Acute toxicity profile of the extract}

The result of acute toxicity test (Table 2) shows that EESAL was not lethal even at the highest dosage (5000 $\mathrm{mg} / \mathrm{kg}$ b.w., p.o.) administered. Similarly, there was no

Table 1 Phytochemical composition of the extract

\begin{tabular}{ll}
\hline Phytochemical constituents & Concentration $\mathbf{( m g / 1 0 0 ~ g )}$ \\
\hline Tannins & $573.28 \pm 30.74$ \\
Terpenoids & $161.75 \pm 3.12$ \\
Steroids & $0.41 \pm 0.08$ \\
Phenols & $3115.16 \pm 143.23$ \\
Alkaloids & $4.62 \pm 1.04$ \\
Flavonoids & $2051.44 \pm 84.32$ \\
Glycosides & $108.54 \pm 12.71$ \\
Saponins & $\mathrm{ND}$ \\
\hline
\end{tabular}

Results are expressed in Mean \pm SD $(n=3)$

ND not detected significant body weight and behavioural changes within the $24 \mathrm{~h}$ observation period post-extract administration. This shows that the extract is tolerable and hence, the median lethal dose $\left(\mathrm{LD}_{50}\right)$ of the extract was therefore assumed to be higher than $5000 \mathrm{mg} / \mathrm{kg}$ body weight.

\section{Effect of EESAL on malaria parasitemia of Plasmodium berghei-infected mice}

After $72 \mathrm{~h}$ post inoculation (before the administration of the extract), there was no significant $(p>0.05)$ difference among the percentage parasitemia of the test mice. However, after the treatment of parasitized mice with artemether (group 3) and graded doses of EESAL (groups 4-6), the percentage malaria parasitemia were significantly $(p<0.05)$ lower than negative control (Table 3). Similarly, EESAL and standard drug suppressed malaria parasite count by comparable percentage, suggesting that EESAL has good antimalarial activity.

\section{Effect of EESAL on some haematological indices of Plasmodium berghei-infected mice}

The pack cell volume (PCV), red blood cell (RBC) and white blood cells (WBC) counts, and haemoglobin ( $\mathrm{Hb}$ ) concentration of negative control mice were lower than normal control. However, administration of graded doses of EESAL to parasitized mice caused significantly $(p<0.05)$ higher PCV, RBC count and Hb concentration when compared with negative control (Table 4).

\section{Effect of EESAL on liver status in Plasmodium berghei- infected mice}

The ALT, ALP and AST activities and total bilirubin concentration of $P$. berghei-infected and untreated mice (negative control) were significantly $(p<0.05)$ higher than normal control. After 4 consecutive days oral treatment with graded doses of EESAL and artemether, $P$. berghei-infected mice in groups 3-6 normalized the liver status (by returning the values of the liver function markers of parasitized-EESAL-treated mice to levels of mice in normal control) (Table 5).

\section{Effect of EESAL on lipid peroxidation and antioxidant parameters of Plasmodium berghei-infected mice}

It was observed that negative control had significantly $(p<0.05)$ higher MDA concentration than normal control. Conversely, negative control had significantly $(p<$ $0.05)$ lower SOD and CAT activities, and GSH concentration than normal control. When malaria-parasitized mice were administered EESAL and artemether, there was a significant $(p<0.05)$ reduction in MDA concentration and elevation in SOD and CAT activities and GSH concentration than negative control. Furthermore, compared to normal control, the lipid peroxidation and 
Table 2 Acute toxicity profile of the extract

\begin{tabular}{lll}
\hline Groups (Treatment) & Mortality & Behavioral and body weight changes \\
\hline Phase I & & Not significant \\
Group $1(10 \mathrm{mg} / \mathrm{kg}$ b.w. EESAL) & $0 / 3$ & Not significant \\
Group $2(100 \mathrm{mg} / \mathrm{kg}$ b.w. EESAL) & $0 / 3$ & Not significant \\
Group $3(100 \mathrm{mg} / \mathrm{kg}$ b.w. EESAL) & $0 / 3$ & Not significant \\
Phase II & & Not significant \\
Group $4(1600 \mathrm{mg} / \mathrm{kg}$ b.w. EESAL) & $0 / 3$ & Not significant \\
Group $5(2900 \mathrm{mg} / \mathrm{kg}$ b.w. EESAL) & $0 / 3$ & $0 / 3$ \\
Group $6(5000 \mathrm{mg} / \mathrm{kg}$ b.w. EESAL) & & \\
\hline
\end{tabular}

antioxidant parameters of parasitized-EESAL-treated mice were not significantly different, suggesting that EESAL has reversed the alterations in lipid peroxidation and antioxidant status (Table 6).

\section{Effect of the EESAL on lipid profile of Plasmodium berghei-infected mice}

Malaria induced significantly $(p<0.05)$ higher serum concentrations of CHOL, LDL, cholesterol and TAGs, but significantly $(p<0.05)$ lower serum HDL concentration in negative control compared to normal control. When administered graded doses of EESAL and artemether for 4 days, parasitized-EESAL-fed mice had significantly $(p<0.05)$ reduced CHOL, LDL and TAGs but significantly $(p<0.05)$ increased HDL concentration compared to negative control (Table 7).

\section{Discussion}

The use of plants as a source of nutrients and drugs is as old as man. Plant products have provided many therapeutic agents, and many conventional drugs have their roots traced from natural sources [45]. The isolation of these natural products is usually based on their uses in traditional practice. S. acuta Burm.f. is used by rural Nigerian dwellers for treating malaria, fever among others [46]. This study examined the ability of crude ethanol leaf extract of $S$. acuta (EESAL) to reduce malaria parasite load and modulate alterations in haematological and biochemical status markers of $P$. berghei-infected mice. The presence of phytochemicals such as alkaloids, terpenoids, glycosides, flavonoids, phenols, steroids and saponins in EESAL suggest that the extract might be bioactive and elicit some pharmacological effects like antioxidant and antimalarial activities [47]. In addition, the lack of any morphological, behavioural and body weight change, and mortality in mice orally administered EESAL up to $5000 \mathrm{mg} / \mathrm{kg}$ b.w after $24 \mathrm{~h}$ showed that the extract is tolerable and safe for consumption. This suggests that the $\mathrm{LD}_{50}$ of EESAL is above $5000 \mathrm{mg} / \mathrm{kg}$ b.w., p.o. This result differs from a report by Konaté et al. [22] that aqueous-acetone extract of $S$. acuta has $\mathrm{LD}_{50}$ of $3.2 \mathrm{~g} / \mathrm{kg}$ b.w. The variation between our result and that of Konaté et al. [22] could be attributed to differences in the solvent of extraction and location of source of the plant. It is documented that substances whose $\mathrm{LD}_{50}$ are above $5000 \mathrm{mg} / \mathrm{kg}$ b.w. p.o are considered safe and non-toxic [48].

The antimalarial activity of EESAL, characterized by significant $(p<0.05)$ dose-dependent decrease in percentage malaria parasitemia and increase in parasite chemosuppression in parasitized-ESSAL-treated mice when compared with negative control could be due to the phytoconstituents of the extract. Extracts of some plants (such as Fagara zanthoxyloides and Erythrina senegalensis leaves and Peltophorum pterocarpum stem bark) that are rich in phytochemicals also present in EESAL have been shown to have antimalarial effects, although with

Table 3 Effect of EESAL on malaria parasitemia of Plasmodium berghei-infected mice

\begin{tabular}{llll}
\hline Groups & Day 0 Malaria parasitaemia (\%) & Day 4 Malaria parasitaemia (\%) & $\begin{array}{c}\text { Chemosuppression } \\
\text { (\%) }\end{array}$ \\
\hline Normal control & $0.00 \pm 0.00^{\mathrm{a}}$ & $0.00 \pm 0.00^{\mathrm{a}}$ & - \\
Negative control & $45.75 \pm 8.18^{\mathrm{b}}$ & $81.75 \pm 2.06^{\mathrm{f}}$ & - \\
MP + $140 \mathrm{mg} / \mathrm{kg}$ b.w. Of Artemether & $42.50 \pm 6.45^{\mathrm{b}}$ & $10.50 \pm 4.12^{\mathrm{e}}$ & $75.29 \pm 3.61^{\mathrm{a}}$ \\
MP + $200 \mathrm{mg} / \mathrm{kg}$ b.w. EESAL & $48.25 \pm 6.34^{\mathrm{b}}$ & $5.00 \pm 0.82^{\mathrm{d}}$ & $89.64 \pm 5.74^{\mathrm{b}}$ \\
MP + $400 \mathrm{mg} / \mathrm{kg}$ b.w. EESAL & $49.50 \pm 4.20^{\mathrm{b}}$ & $2.00 \pm 0.22^{\mathrm{c}}$ & $95.95 \pm 3.71^{\mathrm{bc}}$ \\
MP $+600 \mathrm{mg} / \mathrm{kg}$ b.w. EESAL & $47.75 \pm 3.86^{\mathrm{b}}$ & $1.25 \pm 0.50^{\mathrm{b}}$ & $97.38 \pm 1.87^{\mathrm{c}}$ \\
\hline
\end{tabular}

Results are expressed in Means \pm SD $(n=6)$; At $p<0.05$, mean values with different letters of the alphabets $(a, b, c$, d ...) as superscripts in a column are statically different while mean values with similar alphabets are not statistically different 
Table 4 Effect of the EESAL on some haematological indices in Plasmodium berghei-infected mice

\begin{tabular}{|c|c|c|c|c|}
\hline \multirow[t]{2}{*}{ Groups } & \multicolumn{4}{|c|}{ Haematological indices } \\
\hline & PCV (\%) & RBC $\left(\times 10^{6}\right)$ & WBC $\left(\times 10 \mathrm{~mm}^{3}\right)$ & $\mathrm{Hb}(\mathrm{g} / \mathrm{dl})$ \\
\hline Normal control & $40.75 \pm 1.26^{b c}$ & $10.43 \pm 0.32^{b}$ & $10,525.00 \pm 25.00^{a b}$ & $10.86 \pm 0.35^{c}$ \\
\hline Negative control & $33.75 \pm 3.50^{\mathrm{a}}$ & $8.16 \pm 0.65^{a}$ & $10,025.00 \pm 573.73^{a}$ & $9.53 \pm 0.21^{\mathrm{a}}$ \\
\hline $\mathrm{MP}+140 \mathrm{mg} / \mathrm{kg}$ b.w. of Artemether & $36.75 \pm 3.30^{\mathrm{ab}}$ & $9.82 \pm 0.69^{b}$ & $11,025.00 \pm 741.08^{b}$ & $10.06 \pm 0.29^{b}$ \\
\hline $\mathrm{MP}+200 \mathrm{mg} / \mathrm{kg}$ b.w. EESAL & $41.75 \pm 2.36^{c}$ & $10.64 \pm 0.70^{b}$ & $10,275.00 \pm 95.74^{\mathrm{ab}}$ & $11.13 \pm 0.34^{c}$ \\
\hline $\mathrm{MP}+400 \mathrm{mg} / \mathrm{kg}$ b.w. EESAL & $43.70 \pm 3.50^{c}$ & $10.25 \pm 0.06^{b}$ & $10,325.00 \pm 95.74^{\mathrm{ab}}$ & $11.33 \pm 0.46^{\mathrm{cd}}$ \\
\hline $\mathrm{MP}+600 \mathrm{mg} / \mathrm{kg}$ b.w. EESAL & $43.50 \pm 1.29^{c}$ & $10.61 \pm 0.34^{b}$ & $14,025.00 \pm 602.07^{c}$ & $11.70 \pm 0.20^{d}$ \\
\hline
\end{tabular}

Results are expressed in Means \pm SD $(n=6)$; At $p<0.05$, mean values with different letters of the alphabets $(a, b, c, d \ldots)$ as superscripts in a column are statically different while mean values with similar alphabets are not statistically different

$R B C$ red blood cells, $P C V$ packed cell volume, $W B C$ white blood cells and $H b$ hemoglobin concentration

lower chemosuppression than S. acuta [49-51]. For example, plant-derived flavonoids, alkaloids and terpenoids have been shown to exhibit potent antimalarial activities [52-54].

The observed significant $(p<0.05)$ reduction in total haematological status (PCV value, $\mathrm{Hb}$ concentration, and $\mathrm{RBC}$ and WBC counts) in this study agrees with the results of previous studies both in human [55-57] and rodent [58] malaria. This suppression in RBC count, $\mathrm{PCV}$ and $\mathrm{Hb}$ concentration could be linked to the invasion of erythrocytes by malaria parasites, mechanical devastation of parasitized red cells and the use of $\mathrm{Hb}$ as nutrient source during erythrocytic stage of the parasite life cycle [59]. These haematological aberrations may have resulted from the presence of malaria parasites in the host; malaria parasites release adhesion molecules on the surface of parasitized erythrocytes leading to vascular adhesion. It also leads to the adhesion of both parasitized and non-parasitized erythrocytes, increasing RBCs destruction by splenic clearance [60]. In addition, malaria induces dyserythropoiesis, mitigating restoration of erythropoietic balance [61]. Therefore, the elevation in haematological indices of parasitized-EESAL-treated mice showed that the administration of EESAL ameliorated alterations in haematological status induced by malaria. This ameliorative effect suggests that one or more of the phytoconstituents of the extract is haematopoietic. It could also mean that the clearance of malaria parasite boosted the drive to maintain haematological homeostasis in the host.

Findings of this study showed that mice in the negative control group had significant $(p<0.05)$ elevation in serum activities of AST, ALP and ALT, and concentration of total bilirubin when compared with normal control. This suggests that malaria infection induces hepatotoxicity that may have resulted from the disruption of hepatocyte membrane by inflammatory events associated with byproducts of parasite metabolism. This disruption in the hepatocyte membrane leads to the leakage of intracellular cytosolic enzymes of the hepatocytes into circulation, increasing their activities in the serum. The above result is in line with an earlier report [62]. Similarly, the significantly $(p<0.05)$ higher level of serum total bilirubin in negative control when compared with normal control could be a product of elevated destruction of haemoglobin by the malaria parasite [63]. Bilirubin is a breakdown product of haemoglobin that is usually metabolized in the liver and its accumulation in serum suggests hepatic dysfunction; hence, the estimation of bilirubin level in serum is a useful marker of liver status [64]. The ability of the extract to normalize hepatic status in parasitized mice when compared to control

Table 5 Effect of the EESAL on the liver function parameters in Plasmodium berghei-infected mice

\begin{tabular}{|c|c|c|c|c|}
\hline \multirow[t]{2}{*}{ Groups } & \multicolumn{4}{|c|}{ Liver function markers } \\
\hline & ALT (IU/L) & ALP (IU/L) & AST (IU/L) & T. bil (mg/dl) \\
\hline Normal control & $20.25 \pm 2.63^{a}$ & $64.50 \pm 3.42^{\mathrm{a}}$ & $37.00 \pm 2.58^{\mathrm{a}}$ & $0.45 \pm 0.12^{b}$ \\
\hline Negative control & $36.50 \pm 3.42^{c}$ & $95.25 \pm 6.70^{b}$ & $73.25 \pm 10.63^{b}$ & $0.65 \pm 0.08^{c}$ \\
\hline $\mathrm{MP}+140 \mathrm{mg} / \mathrm{kg}$ b.w. of Artemether & $25.50 \pm 1.91^{b}$ & $62.25 \pm 4.35^{a}$ & $41.25 \pm 0.96^{\mathrm{a}}$ & $0.52 \pm 0.06^{b}$ \\
\hline $\mathrm{MP}+200 \mathrm{mg} / \mathrm{kg}$ b.w. EESAL & $20.50 \pm 1.73^{\mathrm{a}}$ & $67.25 \pm 4.35^{\mathrm{a}}$ & $36.75 \pm 2.99^{a}$ & $0.41 \pm 0.08^{\mathrm{ab}}$ \\
\hline $\mathrm{MP}+400 \mathrm{mg} / \mathrm{kg}$ b.w. EESAL & $26.25 \pm 2.63^{b}$ & $64.75 \pm 3.50^{\mathrm{a}}$ & $34.50 \pm 3.11^{\mathrm{a}}$ & $0.44 \pm 0.02^{\mathrm{ab}}$ \\
\hline $\mathrm{MP}+600 \mathrm{mg} / \mathrm{kg}$ b.w. EESAL & $20.00 \pm 3.74^{\mathrm{a}}$ & $62.25 \pm 2.63^{a}$ & $35.25 \pm 2.50^{\mathrm{a}}$ & $0.37 \pm 0.06^{\mathrm{a}}$ \\
\hline
\end{tabular}

Results are expressed in Means \pm SD $(n=6)$; At $p<0.05$, mean values with different letters of the alphabets $(a, b, c, d \ldots)$ as superscripts in a column are statically different while mean values with similar alphabets are not statistically different

AST aspartate aminotransferase, ALT alanine aminotransferase, ALP alkaline phosphatase, $T$. bil total bilirubin 
Table 6 Effect of the EESAL on lipid peroxidation and antioxidant parameters of Plasmodium berghei-infected mice

\begin{tabular}{|c|c|c|c|c|}
\hline \multirow[t]{2}{*}{ Groups } & \multicolumn{4}{|c|}{ Lipid peroxidation and antioxidant parameters } \\
\hline & MDA Conc. (mg/dl) & SOD activity (IU/L) & CAT activity (IU/L) & GSH Conc. (mg/dl \\
\hline Normal control & $2.68 \pm 0.99^{b}$ & $9.63 \pm 0.42^{b}$ & $0.65 \pm 0.02^{\mathrm{b}}$ & $0.21 \pm 0.05^{a}$ \\
\hline Malaria control & $6.05 \pm 0.68^{c}$ & $4.18 \pm 0.38^{\mathrm{a}}$ & $0.16 \pm 0.05^{c}$ & $0.10 \pm 0.01^{\mathrm{b}}$ \\
\hline $\mathrm{MP}+140 \mathrm{mg} / \mathrm{kg}$ b.w. of Artemether & $2.25 \pm 0.70^{\mathrm{ab}}$ & $9.52 \pm 0.74^{b}$ & $0.66 \pm 0.06^{\mathrm{b}}$ & $0.26 \pm 0.07^{\mathrm{a}}$ \\
\hline $\mathrm{MP}+200 \mathrm{mg} / \mathrm{kg}$ b.w. EESAL & $2.31 \pm 0.39^{\mathrm{ab}}$ & $9.94 \pm 0.58^{b}$ & $0.68 \pm 0.18^{b}$ & $0.22 \pm 0.14^{\mathrm{a}}$ \\
\hline $\mathrm{MP}+400 \mathrm{mg} / \mathrm{kg}$ b.w. EESAL & $2.28 \pm 0.30^{\mathrm{ab}}$ & $9.95 \pm 0.39^{b}$ & $0.72 \pm 0.10^{b}$ & $0.24 \pm 0.05^{\mathrm{a}}$ \\
\hline $\mathrm{MP}+600 \mathrm{mg} / \mathrm{kg}$ b.w. EESAL & $1.54 \pm 0.59^{\mathrm{a}}$ & $10.19 \pm 0.19^{b}$ & $0.68 \pm 0.06^{\mathrm{b}}$ & $0.25 \pm 0.03^{\mathrm{a}}$ \\
\hline
\end{tabular}

Results are expressed in Means \pm SD $(n=6)$; At $p<0.05$, mean values with different letters of the alphabets $(a, b, c$, d ...) as superscripts in a column are statically different while mean values with similar alphabets are not statistically different

MDA malondialdehyde, SOD Superoxide dismutase, CAT catalase, GSH reduced glutathione

suggests that EESAL has normalization effect on hepatocyte integrity of parasitized mice. Hepatic damage from malaria has been linked with oxidative stress, suggesting that the modulation of hepatocytes in this study by the extract could be linked with its antioxidant phytoconstituents.

The involvement of lipids in the development and complications associated with malaria is a matter of recent scientific discussion. Alterations in lipid metabolism in malaria infection, characterized by variation in lipid profile of malaria infected persons when compared with uninfected, have been well documented $[8,11-13]$. The reduction in HDL concentration and elevation in CHOL, LDL and TAGs concentration in Negative control when compared with normal control agrees with the reports of earlier studies $[50,58]$. In mice infected with $P$. chabaudi, Kluck et al. [65] reported higher $\mathrm{CHOL}$ and lower TAGs levels when compared to control. It was further shown that this dyslipidaemia in malaria is exhibited by the inhibition of the AMPK-ACC pathway via reduced 5'AMP-activated protein kinase (AMPK) phosphorylation. The significantly lower HDL level in parasite control mice when compared with normal control might be attributed to a reduction in cholesterol transport, cholesterol esterification by lecithin cholesterol acyl transferase, and inhibition of lipid metabolizing liver enzyme by a parasite factor such as using lipids in the synthesis of haemozoin [66]. In addition, parasite activities might have inhibited HDL-synthesizing enzymes. On the other hand, the elevation in TAGs level might be attributed to an elevation in VLDL synthesis in the liver, due to liver damage as observed in this study. In addition, the hypertriglyceridemia could be attributed to elevated secretion of TAGs in serum and a decline in its clearance by cholesterol ester transfer proteins. As suggested by Khovidhunkit et al. [67], it can be deduced from the above observations that alterations in lipid metabolism in malaria are essentially due to disease-associated mechanisms. In general, the effects of malaria infection in serum lipid status are dependent on malaria parasite species, severity of infection, history of parasite infection, and other host genetic factors. The reduction in levels of CHOL, LDL and TAGs and elevation in HDL levels of parasitized-EESAL-treated mice towards normal control mice showed that the phytoconstituents of the extract might have normalized the lipid status of the parasitized mice.

The increase in the extent of lipid peroxidation which was estimated by the concentration of MDA in negative control when compared with control in this study agrees

Table 7 Effect of the EESAL on lipid profile of Plasmodium berghei-passaged mice

\begin{tabular}{lllll}
\hline Groups & \multicolumn{4}{l}{ Concentration of lipid profile panels } \\
\cline { 2 - 5 } & LDL $(\mathbf{m g} / \mathbf{d l})$ & HDL $(\mathbf{m g} / \mathbf{d l})$ & CHOL $(\mathbf{m g} / \mathbf{d l})$ & TAG $(\mathbf{m g} / \mathbf{d l})$ \\
\hline Normal control & $13.75 \pm 3.86^{\mathrm{ab}}$ & $63.75 \pm 2.63^{\mathrm{b}}$ & $77.25 \pm 2.50^{\mathrm{a}}$ & $94.50 \pm 5.26^{\mathrm{b}}$ \\
Malaria control & $72.25 \pm 3.10^{\mathrm{d}}$ & $29.25 \pm 2.50^{\mathrm{a}}$ & $99.25 \pm 7.46^{\mathrm{b}}$ & $110.75 \pm 2.75^{\mathrm{c}}$ \\
MP + $140 \mathrm{mg} / \mathrm{kg}$ b.w. Of Artemether & $20.25 \pm 2.63^{\mathrm{c}}$ & $68.00 \pm 4.32^{\mathrm{bc}}$ & $95.75 \pm 4.79^{\mathrm{b}}$ & $82.00 \pm 6.32^{\mathrm{a}}$ \\
MP + $200 \mathrm{mg} / \mathrm{kg}$ b.w. EESAL & $16.50 \pm 1.00^{\mathrm{abc}}$ & $73.50 \pm 8.19^{\mathrm{c}}$ & $94.25 \pm 4.03^{\mathrm{b}}$ & $77.75 \pm 8.34^{\mathrm{a}}$ \\
MP + $400 \mathrm{mg} / \mathrm{kg}$ b.w. EESAL & $18.00 \pm 2.16^{\mathrm{bc}}$ & $70.75 \pm 5.10^{\mathrm{c}}$ & $92.00 \pm 3.56^{\mathrm{b}}$ & $81.00 \pm 4.08^{\mathrm{a}}$ \\
MP $+600 \mathrm{mg} / \mathrm{kg}$ b.w. EESAL & $13.00 \pm 2.94^{\mathrm{a}}$ & $73.75 \pm 5.44^{\mathrm{c}}$ & $94.25 \pm 5.12^{\mathrm{b}}$ & $82.25 \pm 9.12^{\mathrm{a}}$ \\
\hline
\end{tabular}

Results are expressed in Means $\pm S D(n=6)$; At $p<0.05$, mean values with different letters of the alphabets $(a, b, c, d \ldots)$ as superscripts in a column are statically different while mean values with similar alphabets are not statistically different CHOL total cholesterol, HDL high density lipoprotein, TAGs triacylglycerols, LDL low density lipoprotein 
with an earlier study in human malaria patients. In agreement with our findings, a reduction in antioxidant status (activities of SOD and level of vitamin C) when compared to healthy control was reported in P. falciparum infected Yemen patients [68]. Similarly, Fabbri et al. [69] showed that $P$. vivax malaria patients have elevated lipid peroxidation status (MDA level) and reduced antioxidant status than healthy control. Similarly, the lower SOD and CAT activities in Negative control mice than normal control is consistent with the findings of D'Souza et al. [70] who also reported that the reduction in the activities of the above antioxidant enzymes was more in $P$. falciparum malaria patients than $P$. vivax malaria patients. It was also reported that the increase in MDA level in $P$. falciparum malaria patients was much more when compared to $P$. vivax malaria patients [71]. In this study, the significant $(p<0.05)$ decrease in the MDA concentration and elevation in the activities of antioxidant enzymes of parasitized mice treated with EESAL compared with Negative control mice could be explained in two ways. Firstly, the extract might be rich in mineral contents that serve as cofactors to these enzymes and hence, increasing their activities. In addition, the phytoconstituents of the extract such as flavonoids which have antioxidant effects could have limited the level of lipid peroxidation. Selenium has been shown to boost antioxidant status and reduce the level of lipid peroxidation in malaria [72]. This is also supported by an earlier study [73] that vitamin E ameliorated P. berghei-induced anaemia and pathological alterations in serum biochemistry.

In a recent study, Ajayi et al. [74] showed that extracts of Vernonia amygdalina and Tithonia diversifolia at 400 $\mathrm{mg} / \mathrm{kg}$ suppressed $P$. berghei in mice by $75 \%$ and $66 \%$, respectively which were lower than $95.95 \%$ recorded in the present study. In addition, Muluye et al. [75] showed that root extract of Euphorbia abyssinica at 200, 400 and $600 \mathrm{mg} / \mathrm{kg}$ respectively gave $66.87 \%, 84.94 \%$ and $93.69 \%$ chemosuppression of $P$. berghei infection in mice which were however, lower than the suppression by $S$. acuta extract in the present study. A similar lower chemosuppression malaria parasite $(71.93 \%, 80.97 \%$ and $85.64 \%$ at 100, 200, and $400 \mathrm{mg} / \mathrm{kg}$ ) was recorded by Terminalia mantaly stem bark water extract [76]. Furthermore, Biruk et al. [77] reported that at $400 \mathrm{mg} / \mathrm{kg}$ each, aqueous-methanol and water extracts of Terminalia brownie bark had lower chemosuppression (61.2 and $51.1 \%$, respectively) compared with the results of this study. The higher malaria chemosuppression by EESAL relative to many other plant extracts, and its ability to abrogate alterations in hematology and biochemical status of malaria-passaged mice has made a potential source of new antimalarial agent(s). Interestingly, some Sida secondary metabolites including stigmasterol and its derivative, stigmasterol-3-O- $\beta$-D-glucopyranoside, have been shown to exhibit antimalarial properties [53, 78]. Similarly, the presence of high levels of flavonoids, alkaloids, terpenoids and tannins which have been known to have antimalarial and chemoprotective activities could be responsible for the findings of the present study $[27,79,80]$. This study has some limitations such as the inability to track the specific compounds responsible for the antimalarial activities of EESAL and characterize them and inability to evaluate the specific mechanism of killing the parasites by EESAL. Hence, this study is considered a preliminary study which has opened the door for further in-depth investigation of the active ingredients through activity-guided fractionation and characterization using chromatographic and spectroscopic techniques which are currently going on in our laboratory. However, findings of this study generally demonstrate that EESAL has antimalarial property, modulates oxidative stress, and rescues haematological aberrations and abrogated dyslipidemia and hepatic dysfunction associated with malaria.

\section{Conclusion}

From the above results, it can be concluded that by reducing parasite density in infected mice, EESAL exhibits antimalarial properties. The findings also showed that EESAL normalized the haematological and some biochemical status altered by malaria. This suggests that the plant is a potential reserve of novel antimalarial agents; hence, isolation of specific components of the extract responsible for the above biological activities using bioassay-guided fractionation is warranted. In addition, the specific molecular mechanism(s) of action of the extract and its active compounds are unknown and hence, recommended for further investigations.

\section{Abbreviations}

EESAL: Ethanol extract of Sida acuta leaves; PCV: Packed cell volume;

Hb: Haemoglobin; RBC: Red blood cell; WBC: White blood cell; AST: Aspartate aminotransferase; ALT: Alanine aminotransferase; ALP: Alkaline phosphatase; MDA: Malondialdehyde; CHOL: Cholesterol; LDL: Low-density lipoprotein; HDL: High-density lipoprotein; TAG: Triacylglycerol/triglyceride; $\mathrm{LD}_{50}$ : Median lethal dose; CAT: Catalase; GSH: Reduced glutathione; SOD: Superoxide dismutase; PVS: Polyvinyl sulphate; SD: Standard deviation; PK: 5'AMPactivated protein kinase

\section{Acknowledgements}

Not applicable.

\section{Authors' contributions}

Conceptualization, OCE and CCA; data curation and analysis, IUO, PCO, CAN, TCU, EAA, ACN and BCC; writing - original draft preparation, OCE, CCA and IUO.; writing-review and editing, IUO. and CCA. All authors have read and agreed to the published version of the manuscript.

Funding

Not applicable.

Availability of data and materials

Available from the corresponding author upon reasonable request. 


\section{Declarations}

\section{Ethics approval and consent to participate}

The study protocols were approved by the Faculty of Biological Sciences Committee on Research Ethics, University of Nigeria, Nsukka (UNN/FBS/EC/ 102). Other national and international guidelines for the care and use of animals for research were strictly followed in this study.

\section{Consent for publication}

Not applicable.

\section{Competing interests}

The authors declare that they have no competing interests.

\section{Author details}

'Department of Biochemistry, Ethnomedicinal and Pharmacological Biochemistry Unit, University of Nigeria, Nsukka, Enugu State, Nigeria. ${ }^{2}$ Department of Biochemistry, Medical Parasitology, Toxicology and Drug development Unit, University of Nigeria, Nsukka, Enugu State, Nigeria.

Received: 9 April 2021 Accepted: 1 October 2021

Published online: 11 October 2021

\section{References}

1. World Health Organization (WHO). 2017 world malaria report factsheet. Geneva; 2018. https://www.who.int/news-room/fact-sheets/detail/malaria. Accessed 28 Sept 2019

2. World Health Organization (WHO). World malaria report 2019. 2019. https:// www.who.int/malaria/publications/world-malaria-report-2019/en/. Accessed 5 Feb 2020.

3. Fairhurst RM, Dondorp AM. Artemisinin-resistant Plasmodium falciparum malaria. Microbiol Spectr. 2006;4(3):12-21.

4. Suresh $\mathrm{N}$, Haldar K. Mechanisms of artemisinin resistance in Plasmodium falciparum malaria. Curr Opin Pharmacol. 2018;42:46-54. https://doi.org/10.1 016/j.coph.2018.06.003.

5. Luo Y, Che M, Liu C, et al. Toxicity and related mechanisms of dihydroartemisinin on porcine oocyte maturation in vitro. Toxicol Appl Pharmacol. 2018;341:8-15. https://doi.org/10.1016/j.taap.2018.01.002.

6. Sakzabre D, Asiamah EA, Akorsu EE, Abaka-Yawson A, Dika ND, Kwasie DA, et al. Haematological profile of adults with malaria parasitaemia visiting the Volta regional hospital, Ghana. Adv Hematol. 2020;9369758:1-6. https://doi. org/10.1155/2020/9369758.

7. Esan AJ, Omisakin CT, Titilayo OE, Fasakin KA. Gender difference on stress induced by malaria parasite infection and effect of anti-malaria drug on stress index. Am J Biomed Res. 2014;2(3):42-6. https://doi.org/10.12691/a jbr-2-3-1.

8. Mohanty S, Mishra SK, Das BS, Satpathy SK, Mohanty D, Patnaik JK, et al. Altered plasma lipid pattern in falciparum malaria. Ann Trop Med Parasitol. 1992;86(6):601-6. https://doi.org/10.1080/00034983.1992.11812715.

9. Dias RM, Vieira JLF, Cabral BC, et al. Lipid profile of children with malaria by Plasmodium vivax. J Trop Med. 2016;9052612:1-5. https://doi.org/10.1155/2 016/9052612.

10. Babaliche $P$, Gubba P. Variation in common serum lipid parameters in patients with malaria: a 1-year cross-sectional study. J Curr Res Sci Med. 2019;5(1):39-43. https://doi.org/10.4103/jcrsm.jcrsm_1_19.

11. Sirak S, Fola AA, Worku L, Biadgo B. Malaria parasitemia and its association with lipid and haematological parameters among malaria-infected patients attending at Metema Hospital, Northwest Ethiopia. Pathol Lab Med Int. 2016;8:43-50. https://doi.org/10.2147/PLMI.S118946.

12. Visser BJ, de Vries SG, Vingerling R, et al. Serum lipids and lipoproteins during uncomplicated malaria: a cohort study in Lambaréné, Gabon. Am J Trop Med Hyg. 2017;96(5):1205-14. https://doi.org/10.4269/ajtmh.16-0721.

13. Chikezie PC, Okpara RT. Serum lipid profile and hepatic dysfunction in moderate Plasmodium falciparum infection. Sci J Microbiol. 2013;2(8):158-65.

14. Dungdung A, Jalawadi VM, Yadav UP. Study of serum lipid profile in Plasmodium falciparum malaria. Int J Res Med Sci. 2018;6(11):3673-7. https:// doi.org/10.18203/2320-6012.ijrms20184428.

15. Orimadegun $A E$, Orimadegun BE. Serum apolipoprotein-A1 and cholesterol levels in Nigerian children with Plasmodium falciparum infection. Med Princ Pract. 2015;24(4):318-24. https://doi.org/10.1159/000430812.
16. Agbodeka K, Gbekley HE, Karou SD, Anani K, Agbonon A, Tchacondo T, et al. Ethnobotanical study of medicinal plants used for the treatment of malaria in the plateau region, Togo. Phcog Res. 2016;8:S12-8. https://doi. org/10.4103/0974-8490.178646.

17. Abat JK, Kumar S, Mohanty A. Ethnomedicinal, phytochemical and ethnopharmacological aspects of four medicinal plants of Malvaceae used in Indian traditional medicines: a review. Medicines. 2017;4(4):75. https://doi. org/10.3390/medicines4040075.

18. Builders MI. African traditional antimalarials: a review. Pharm Chem J. 2017; 4(6):87-98.

19. Ignacimuthu S, Ayyanar M, Sankara-Sivaramann K. Ethnobotanical investigations among tribes in Madurai District of Tamil Nadu (India). J Ethnobiol Ethnomed. 2006;2(1):25-31. https://doi.org/10.1186/1746-4269-2-25.

20. Aarthi N, Murugan $K$, Madhiyazhagan $P$, et al. Studies on the effect of Sida acuta and Vetiveria zizanioides against the malarial vector, Anopheles stephensi and malarial parasite, Plasmodium berghei. Int J Pure Appl Zool. 2014:2(1):51-60.

21. Banzouzi JT, Prado R, Menan H, Valentin A, Roumestan C, Mallié M, et al. Studies on medicinal plants of Ivory Coast: investigation of Sida acuta for in vitro antiplasmodial activities and identification of an active constituent. Phytomedicine. 2004;11(4):338-41. https://doi.org/10.1078/0944711041495245.

22. Konaté K, Bassolé $I H N$, Hilou A, et al. Toxicity assessment and analgesic activity investigation of aqueous acetone extracts of Sida acuta Burn $\mathrm{f}$. and Sida cordifolia L. (Malvaceae), medicinal plants of Burkina Faso. BMC Complement Altern Med. 2012;12:120. https://doi.org/10.1186/1472 6882-12-120.

23. Mbajiuka CS, Obeagu El, Ochei KC, Nnadi DC. The antibacterial activity of leaf extracts of Ocimum gratissimum and Sida acuta. Intl J Microbiol Res. 2014;5(2):124-9. https://doi.org/10.1186/1472-6882-12-120.

24. Krishnaveni A, Ezhilarasan B, lyappan A, Sathali AAH. Preliminary phytochemical screening and in vitro antioxidant activity of Sida acuta Burm. Int J Res Pharmacol Pharmacother. 2018:7(2):157-65.

25. Benjumea DM, Gómez-Betancur IC, Vásquez J, Alzate F, García-Silva A, Fontenla JA. Neuropharmacological effects of the ethanolic extract of Sida acuta. Rev Bras Farmacogn. 2016;26(2):209-15. https://doi.org/10.1016/j.bjp.2 015.09.011.

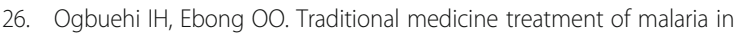
Onitsha, south East Nigeria. Greener J Med Sci. 2015;5(1):11-8. https://doi. org/10.15580/GJMS.2015.1.051114384.

27. Adesina DA, Adefolalu SF, Jigam AA, Lawal B. Antiplasmodial effect and sub-acute toxicity of alkaloid, flavonoid and phenolic extracts of Sida acuta leaf on PLasmodium berghei-infected animals. J Taibah Uni Sci. 2020;14(1): 943-53. https://doi.org/10.1080/16583655.2020.1790912.

28. Trease GE, Evans WC. Pharmacognosy. 13th ed. Bailliere Tindall Books Publishers. London: Cas Sell and Collines Macmillan Publishers Ltd: 1989.

29. Harborne JB. Textbook of phytochemical method. 3rd ed. London: Champmaan and Hall Ltd.; 1998.

30. Ogbu CP, Okagu IU, Nwodo OF. Anti-inflammatory activities of ethanol extract of Combretum zenkeri leaves. Comp Clin Pathol. 2020;29(2):397-409. https://doi.org/10.1007/s00580-019-03072-0.

31. Lorke D. A new approach to practical acute toxicity testing. Arch Toxicol. 1983;54(4):275-87. https://doi.org/10.1007/BF01234480.

32. Bain BJ. Preparation and staining methods for blood and bone marrow films. In: Dacie and Lewis practical haematology. 12th ed. UK: Elsevier; 2017. p. 1-11. https://doi.org/10.1016/B978-0-7020-6696-2.00004-7.

33. Osei-Bimpong A, Burthem J. Supplementary techniques including blood parasite diagnosis. In: Dacie and Lewis practical haematology. 12th ed. UK: Elsevier; 2017. p. 101-17. https://doi.org/10.1016/B978-0-7020-6696-2.00006-0.

34. Ochei J, Kolhatkar A. Medical laboratory science theory and practice. New York: McGraw Hill; 2008. p. 663-5.

35. Briggs C, Bain BJ. Basic haematological techniques. In: Dacie and Lewis practical haematology. 12th ed. UK: Elsevier; 2017. p. 18-49. https://doi. org/10.1016/B978-0-7020-6696-2.00003-5.

36. Reitman S, Frankel S. A colorimetric method for the determination of serum glutamic oxaloacetic and glutamic pyruvic transaminases. Am J Clin Pathol. 1957;28(1):56-63. https://doi.org/10.1093/ajcp/28.1.56.

37. Klein B, Read PA, Babson AL. Rapid method for the quantitative determination of serum alkaline phosphatase. Clin Chem. 1960;6(2):269-75. https://doi.org/10.1093/clinchem/6.3.269.

38. Jendrassik L Grof P. In vitro determination of total and direct bilirubin Biochemica. 1938;297:81-9. 
39. Allain CC, Poon LS, Chain CSG. Enzymatic determination of total serum cholesterol. Clin Chem. 1974;20(4):470-5. https://doi.org/10.1093/clinchem/2 0.4 .470 .

40. Albers JJ, Warmick GR, Cheng MC. Determination of high-density lipoprotein (HDL)-cholesterol. Lipids. 1978;13(12):926-32. https://doi.org/10.1 007/BF02533852.

41. Wallin B, Rosengren B, Shertzer HG, Camejo G. Lipoprotein oxidation and measurement of TBARS formation in single microlitre plate: its use for evaluation of antioxidants. Anal Biochem. 1993;208(1):10-5. https://doi.org/1 $0.1006 / a b i o .1993 .1002$

42. Xin Z, Waterman DF, Henken RM, Harmon RJ. Effects of copper status on neutrophil function, superoxide dismutase and copper distribution in steers. J Diary Sci. 1991;74(9):3078-82. https://doi.org/10.3168/jds.S0022-0302(91 )78493-2.

43. Aebi HE. Catalase. In: Bergmeyer HU, editor. Methods of enzymatic analysis. Weinhem: Verlag Chemie; 1983. p. 273-86

44. King KJ, Wootton IDP. Microanalysis in medical biochemistry. 3rd ed London: J and A Churchill; 1959. p. 50-4.

45. Mohideen S, Sasikala E, Gopal V. Pharmacognostic studies on Sida acuta burm. Anc Sci Life. 2002;22(1):57-66.

46. Adebayo JO, Krettli AU. Potential antimalarials from Nigerian plants: a review. J Ethnopharmacol. 2011;133(2):289-302. https://doi.org/10.1016/j. jep.2010.11.024.

47. Saxena M, Saxena J, Nema R, et al. Phytochemistry of medicinal plants. J Pharmacogn Phytochem. 2013;1(6):168-82.

48. Kennedy GL, Ferenz RLJ, Burgess BA. Estimation of acute toxicity in rats by determination of the approximate lethal dose rather than the $L_{50}$. J Appl Toxicol. 1986;6(3):145-8. https://doi.org/10.1002/jat.2550060302.

49. Enechi OC, Okagu IU, Ndefo JC, et al. Methanol extract of Peltophorum pterocarpum stem bark has antimalarial activity and normalizes biochemical changes induced by Plasmodium berghei infection. Adv Life Sci Tech. 2019; 73:43-55.

50. Enechi OC, Amah CC, Okagu IU, Ononiwu CP, Azidiegwu VC, Ugwuoke EO, et al. Methanol extracts of Fagara zanthoxyloides leaves possess antimalarial effects and normalizes haematological and biochemical status of Plasmodium berghei-passaged mice. Pharm Biol. 2019;57(1):577-85. https:// doi.org/10.1080/13880209.2019.1656753.

51. Joshua PE, Okoro IJ, Ekpo DE, Okagu IU, Ogugua VN. Methanol extract of Erythrina senegalensis leaves (MEES) ameliorates Plasmodium berghei-ANKA 65-parasitised aberrations in mice. All Life. 2020;13(1):66-77. https://doi.org/1 0.1080/26895293.2020.1718777.

52. Lehane AM, Saliba KJ. Common dietary flavonoids inhibit the growth of the intraerythrocytic malaria parasite. BMC Res Notes. 2008;1(1):26. https://doi. org/10.1186/1756-0500-1-26.

53. Onguéné PA, Ntie-Kang F, Lifongo LL, Ndom JC, Sippl W, Mbaze LM. The potential of anti-malarial compounds derived from African medicinal plants, part I: a pharmacological evaluation of alkaloids and terpenoids. Malar J. 2013;12(1):449. https://doi.org/10.1186/1475-2875-12-449.

54. Soré H, Sanon S, Hilou A. Antiplasmodial properties of plants isolated flavonoids and their derivatives. Int J Herb Med. 2018;6(5):43-56.

55. Igbenegbu C, Odaibo AB. Impairs of acute malaria on some haematological parameters in a semi-urban community in southwestern Nigeria. Acta Parasitol Glob. 2013:4(1):1-5.

56. Eledo BO, Izah SC. Studies on some haematological parameters among malaria infected patients attending a tertiary hospital in Nigeria. Blood Res Trans J. 2018;2(3):1-5.

57. Kotepui M, Punsawad C, Kotepui KU, Somsak V, Phiwklam N, PhunPhuech B. Prevalence of malarial recurrence and haematological alteration following the initial drug regimen: a retrospective study in Western Thailand. BMC Public Health. 2019;19(1):1294. https://doi.org/10.1186/s12889-019-7624-1.

58. Ogugua VN, Okagu IU, Onuh OM, Uzoegwu PN. Commercial herbal preparations ameliorate Plasmodium berghei NK65-induced aberrations in mice. J Vector Borne Dis. 2019;56(2):146-53. https://doi.org/10.4103/09729062.263722.

59. Francis $U$, Isaac Z, Yakubu A, et al. Haematological parameters of malariainfected patients in the university of Calabar teaching hospital, Calabar, Nigeria. J Hematol Thromb Dis. 2014;2:171. https://doi.org/10.4172/23298790.1000171
60. White NJ. Anaemia and malaria. Malar J. 2018;17(1):371. https://doi.org/10.11 86/s12936-018-2509-9.

61. Milner EM, Kariger P, Pickering AJ, Stewart CP, Byrd K, Lin A, et al. Association between malaria infection and early childhood development mediated by anemia in rural Kenya. Int J Environ Res Public Health. 2020; 17(3):902. https://doi.org/10.3390/ijerph17030902.

62. Enechi OC, Ugwu OPC. Histopathological studies of liver function in rats fed on ginger lily corn meal. Mintage J Pharm Med Sci. 2013;2(3):55-8.

63. Trampuz A, Jereb MJ, Muzlovi Cl, Prabhu RM. Clinical review: severe malaria. Crit Care. 2003;7(4):315-23. https://doi.org/10.1186/cc2183.

64. Orabueze Cl, Ota DA, Coker HA. Antimalarial potentials of Stemonocoleus micranthus harms (leguminoseae) stem bark in Plasmodium berghei infected mice. J Tradit Complement Med. 2020;10(1):70-8. https://doi.org/10.1016/j. jtcme.2019.03.001.

65. Kluck GEG, Wendt CHC, Do Imperio GE, et al. Plasmodium infection induces dyslipidemia and a hepatic lipogenic state in the host through the inhibition of the AMpK-Acc pathway. Sci Rep. 2019;9(1):14695. https://doi. org/10.1038/s41598-019-51193-X.

66. Visser BJ, Wieten RW, Nagel IM, Grobusch MP. Serum lipids and lipoproteins in malaria - a systematic review and meta-analysis. Malar J. 2013;12(1):442. https://doi.org/10.1186/1475-2875-12-442.

67. Khovidhunkit W, Kim MS, Memon RA. Effects of infection and inflammation on lipid and lipoprotein metabolism: mechanisms and consequences to the host. J Lipid Res. 2004;45(7):1169-96. https://doi.org/10.1194/jlr.R300019-JLR2 00 .

68. Ezzi AAA, Salahy MBA, Shnawa BH, et al. Changes in levels of antioxidant markers and status of some enzyme activities among falciparum malaria patients in Yemen. J Microbiol Exp. 2017;4(6):00131. https://doi.org/10.154 06/jmen.2017.04.00131.

69. Fabbri C, Mascarenhas-Netto RC, Lalwani P, et al. Lipid peroxidation and antioxidant enzymes activity in Plasmodium vivax malaria patients evolving with cholestatic jaundice. Malar J. 2013;12(1):315. https://doi.org/10.1186/14 75-2875-12-315

70. D'Souza B, D'Souza V, Swagata H, et al. Erythrocyte antioxidant enzymes and their correlation with malondialdehyde in malaria. Biomed Res. 2009;20(1): 25-7. https://doi.org/10.1016/s0035-9203(99)90180-3.

71. Adebayo AH, Olasehinde Gl, Egbeola OA, et al. Enhanced antioxidant capacity following selenium supplemented antimalarial therapy in Plasmodium berghei infected mice, Proceedings of the 2nd International Conference on Applied Sciences, American Institute of Physics (AIP) Conference Proceedings 1954; 2018. p. 030019.

72. Ibrahim MA, Zuwahu MMB, Isah MB, Jatau ID, Aliyu AB, Umar IA. Effects of vitamin E administration on Plasmodium berghei induced pathological changes and oxidative stress in mice. Trop Biomed. 2012;29(1):98-106. https://doi.org/10.1007/s00580-011-1348-7.

73. Ajayi CO, Elujoba AA, Okella H, Oloro J, Raymond A, Weisheit A, et al. In vivo antimalarial activities of five Ugandan medicinal plants on Plasmodium berghei in mice. Eur J Med Plants. 2020;31(12):1-13. https://doi.org/10.9734/ ejmp/2020/v31i1230300

74. Muluye AB, Desta AG, Abate SK, Dano GT. Anti-malarial activity of the root extract of Euphorbia abyssinica (Euphorbiaceae) against Plasmodium berghei infection in mice. Malar J. 2019;18(1):261. https://doi.org/10.1186/s12936-01 9-2887-7.

75. Tali MBT, Mbouna CDJ, Tchokouaha LRY, et al. In vivo antiplasmodial activity of Terminalia mantaly stem bark aqueous extract in mice infected by Plasmodium berghei. J Parasitol Res. 2020;2020:4580526-9. https://doi.org/1 $0.1155 / 2020 / 4580526$.

76. Biruk H, Sentayehu B, Alebachew Y, et al. In vivo antimalarial activity of $80 \%$ methanol and aqueous bark extracts of Terminalia brownii Fresen. (Combretaceae) against Plasmodium berghei in mice. Biochem Res Int. 2020: 9749410. https://doi.org/10.1155/2020/9749410.

77. Woldeyes S, Adane L, Tariku Y, et al. Evaluation of antibacterial activities of compounds isolated from Sida rhombifolia Linn. (Malvaceae). Nat Prod Chem Res. 2012;1:1. https://doi.org/10.4172/2329-6836.1000101.

78. Sahoo RK, Tamuli KJ, Lhouvum N, Dutta D, Bordoloi M, Sharma HK, et al. Phytochemical constituents from Xanthium strumarium $\mathrm{L}$. and evaluation of their in vitro antimalarial activities. S Afr J Botany. 2020;135:35-40. https:// doi.org/10.1016/j.sajb.2020.08.006. 
79. Ntie-Kang F, Onguéné PA, Lifongo LL, Ndom JC, Sippl W, Mbaze LM'. The potential of anti-malarial compounds derived from African medicinal plants, part II: a pharmacological evaluation of non-alkaloids and non-terpenoids. Malar J. 2014;13(1):81. https://doi.org/10.1186/1475-2875-13-81.

80. Batista R, Júnior AJS, de Oliveira AB. Plant-derived antimalarial agents: new leads and efficient phytomedicines. Part II. Non-alkaloidal natural products. Molecules. 2009;14(8):3037-72. https://doi.org/10.3390/molecules14083037.

\section{Publisher's Note}

Springer Nature remains neutral with regard to jurisdictional claims in published maps and institutional affiliations.

Submit your manuscript to a SpringerOpen ${ }^{\circ}$ journal and benefit from:

- Convenient online submission

- Rigorous peer review

- Open access: articles freely available online

- High visibility within the field

- Retaining the copyright to your article

Submit your next manuscript at $\boldsymbol{\wedge}$ springeropen.com 